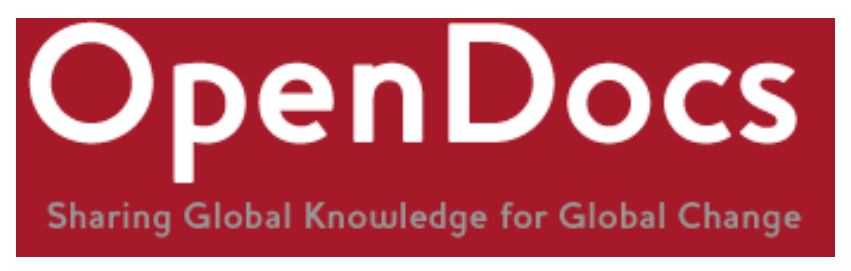

Title: At the limits of spatial governmentality: a message from the tip of Africa

Citation: Robins, Steven (2002) 'At the limits of spatial governmentality: a message from the tip of Africa', Third World Quarterly, 23: 4, 665 - 689. DOI: 10.1080/0143659022000005328

Official URL: $\underline{\text { http://dx.doi.org/10.1080/0143659022000005328 }}$

More details/abstract: Urban studies scholars drawing on Foucault's analysis of govern- mentality have investigated how urban social orders are increasingly more concerned with the management of space rather than on the discipline of offenders or the punishment of offences (Merry, 2001). This paper examines the 'rationality' and efficacy of spatial governmentality in post-aparthei d Cape Town, and shows how the city has increasingly become a 'fortress city' (Davis, 1990), much like cities such as Los Angeles, Sao Paolo and Rio de Janeiro. These 'global cities' are increasingly characterised by privatised security systems in middle class suburbs, shopping malls and gated communities (Caldeira, 1999). These spatial forms of governmentality draw on sophisticated security systems comprising razor wire and electrified walls, burglar alarms and safe rooms, as well as vicious guard dogs, neighbourhood watches, private security companies, and automated surveillance cameras. On the other side of the race and class divide are urban ghettoes characterised by growing poverty and everyday violence. These socio-spatial inequalities continue to be reproduced despite urban planning initiatives aimed at desegregating the apartheid city. Although the media and the middle classes highlight the dangers of crime and violence, they tend to ignore the structures of inequality that fuel the growth of crime syndicates and violent drug economies that are reproducing these urban governance crises. Given the diminished resources of the neo-liberal state, the policing of middle class residential and business districts is increasingly being 'outsourced' to private security companies. In working class neighbourhoods of Cape Town such as Manenberg, the state has attempted to re-establish governance by resorting to new forms of spatial governmentality. The paper draws attention to the limits of these attempts to assert state control through the management of space. Spatial governance in places like Manenberg will continue to be relatively ineffectual given existing levels of social inequality and racial polarization. Such processes are reproduced by massive unemployment and racialised poverty resulting from socio-spatial legacies of apartheid and Cape Town's shift from a manufacturing to a tourist, IT and financial services economy. Although this paper focuses on attempts at re-establishing governance in a crime and gangster-ridden working class neighbourhood of Cape Town, it addresses these issues in relation to city-wide shifts to new forms of spatial governmentality after apartheid.

Version: Published version

Terms of use: Full terms and conditions of use:http://www.informaworld.com/terms-and-conditions-ofaccess.pdf

This article may be used for research, teaching and private study purposes. Any substantial or systematic reproduction, re-distribution, re-selling, loan or sub-licensing, systematic supply or

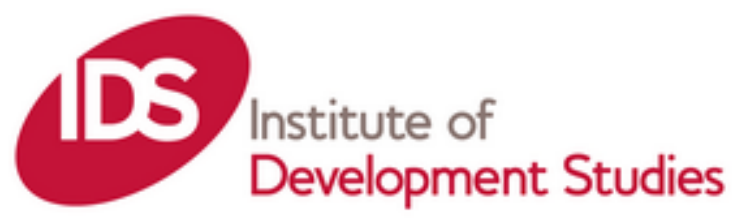


distribution in any form to anyone is expressly forbidden. The publisher does not give any warranty express or implied or make any representation that the contents will be complete or accurate or up to date. The accuracy of any instructions, formulae and drug doses should be independently verified with primary sources. The publisher shall not be liable for any loss, actions, claims, proceedings, demand or costs or damages whatsoever or howsoever caused arising directly or indirectly in connection with or arising out of the use of this material.

This is a download from OpenDocs at the Institute of Development Studies

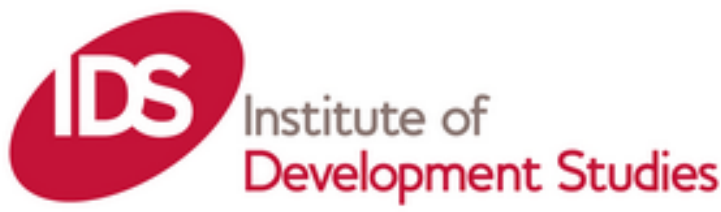




\section{At the limits of spatial governmentality: a message from the tip of Africa}

\section{STEVEN ROBINS}

ABSTRACT Urban studies scholars drawing on Foucault's analysis of governmentality have investigated how urban social orders are increasingly more concerned with the management of space rather than on the discipline of offenders or the punishment of offences (Merry, 2001). This paper examines the 'rationality' and efficacy of spatial governmentality in post-apartheid Cape Town, and shows how the city has increasingly become a 'fortress city' (Davis, 1990), much like cities such as Los Angeles, Sao Paolo and Rio de Janeiro. These 'global cities' are increasingly characterised by privatised security systems in middle class suburbs, shopping malls and gated communities (Caldeira, 1999). These spatial forms of governmentality draw on sophisticated security systems comprising razor wire and electrified walls, burglar alarms and safe rooms, as well as vicious guard dogs, neighbourhood watches, private security companies, and automated surveillance cameras. On the other side of the race and class divide are urban ghettoes characterised by growing poverty and everyday violence. These socio-spatial inequalities continue to be reproduced despite urban planning initiatives aimed at desegregating the apartheid city. Although the media and the middle classes highlight the dangers of crime and violence, they tend to ignore the structures of inequality that fuel the growth of crime syndicates and violent drug economies that are reproducing the se urban governance crises. Given the diminished resources of the neo-liberal state, the policing of middle class residential and business districts is increasingly being 'outsourced' to private security companies. In working class neighbourhoods of Cape Town such as Manenberg, the state has attempted to re-establish governance by resorting to new forms of spatial governmentality. The paper draws attention to the limits of these attempts to assert state control through the management of space. Spatial governance in places like Manenberg will continue to be relatively ineffectual given existing levels of social inequality and racial polarization. Such processes are reproduced by massive unemployment and racialised poverty resulting from socio-spatial legacies of apartheid and Cape Town's shift from a manufacturing to a tourist, IT and financial services economy. Although this paper focuses on attempts at re-establishing governance in a crime and gangster-ridden working class neighbourhood of Cape Town, it addresses these issues in relation to city-wide shifts to new forms of spatial governmentality after apartheid. 
Major elements of instability in the neoliberal scenario [include] the downward trend in corporate taxes and the inability to finance common goods, nationally and globally ... Without taxation, no infrastructure. Without taxation, no proper education, no affordable health care. Without taxation, no public sphere. Without a public sphere, no legitimacy. Without legitimacy, no security. This in itself is a familiar future scenario. It could take the form of global 'Californianization' while California is being 'Brazilianized'. A world of gated communities, high barbed-wire fences, steep hierarchies, robots on the workfloor and at the gate, and automated surveillance all around. A world of creeping privatization of public space, as in Los Angeles (cf. Mike Davis' City of Quartz (1990). A 'post-human' world ... of which we see one face in Blade Runner and other cinematic dystopias. (Nederveen Pieterse, 2000: 11)

Cape Town's city managers and planners imagine their city's future as a globally competitive city with advanced IT and financial service sectors, and a booming tourism industry with world-class hotels and convention centres, a Californian dreamscape at the tip of Africa. Although the 'Californianization'" of Cape Town is indeed taking place, it seems to be replicating itself less as Africa's Silicon Valley than as a fortress city of gated communities (Caldeira, 1996: 2000), 'zerotolerance' policing, community policing strategies (eg neighbourhood watches, commandos and vigilante groups), private security companies, automated surveillance cameras, ${ }^{2}$ high barbed-wire fencing and vicious guard dogs on one side of the divide, and urban ghettoes of racialised poverty and violence on the other (Davis, 1990; Nederveen Pieterse, 2000). After apartheid, the black 'townships' of Cape Town have become even more segregated and disconnected from the 'white' middle class parts of the city. In a context of rising levels of crime and violence, the townships are perceived by middle class suburban residents to be even more dangerous and 'unruly' than they were under apartheid.

Despite concerted city-wide planning initiatives aimed at desegregating the apartheid city, the everyday socio-spatial legacies of apartheid continue to be reproduced: middle class Capetonians seldom venture near the townships and fears of 'black crime' continue to fuel a booming security industry and a fortified architecture of fear in the leafy middle class suburbs and shopping malls (Davis, 1990). While the media and the middle classes regard the unacceptably high levels of crime and violence as an indication of a severe crisis of governance, there is a loud silence on the role of neoliberal policies in reproducing the conditions of poverty and unemployment that sustain these violent economies. With the limited state resources available for policing, as in so many cities in the North, the policing of middle class residential and business districts is being outsourced to private security companies, resulting in new forms of spatial governance (Merry, 2001). Although this paper focuses on attempts at reestablishing governance in a crime- and gangster-ridden working class neighbourhood of Cape Town, it addresses these issues in relation to city-wide shifts to forms of 'spatial governmentality'.

Sally Merry (2001: 16) writes that whereas 'modern penality is largely structured around the process of retraining the soul rather than corporal punishment, recent scholarship has highlighted another regime of governance: control through the management of space'. According to Merry (2001: 16-17): 
New forms of spatially organized crime control characterize contemporary cities, from the explosion of gated communities (Caldeira, 1999), to 'prostitution free zones' as a regulatory strategy for the sex trade (Perry and Sanchez, 1998: Sanchez, 1997) to 'violence free zones' as a way of diminishing communal conflict in India. Spatialized strategies have been applied to the control of alcohol consumption (Valverde, 1998) and the regulation of smoking ... New community-policing strategies towards youth emphasize moving potentially criminal youths to other areas rather than prosecuting them (Ericson and Haggerty, 1999: 169). These are all examples of new regulatory mechanisms that target spaces rather than persons. They exclude offensive behavior rather than attempting to correct or reform offenders. The regulation of space through architectural design and security devices is generally understood as a complement to disciplinary penality but fundamentally different in its logic and technologies (Ewick, 1997; Shearing and Stenning, 1985; Shields, 1989; Simon, 1988; Valverde et al, 1999).

This paper seeks to understand the implications for democracy and citizenship of new forms of spatial governmentality that contribute to socio-spatial exclusions in an already highly segregated apartheid city. Spatial governance and the privatisation of public space seem to emerge in contexts of increasing racial and class polarisation and rising unemployment and poverty. These governance initiatives are also taking place in contexts in which the contracting and retreating neoliberal state (and its security apparatus) is increasingly helpless in the face of dramatically escalating levels of violent crime and social disorder. This is exacerbated by the fact that large sections of the urban underclass do not seem to buy into the liberal democratic values of citizenship, given their limited access to economic and political rights in a context of jobless growth and structural unemployment. It will become clear in the following pages that these developments have placed enormous obstacles in the way of attempts by the South African state to re-establish governance following decades of state violence and systematic race and class inequalities under apartheid.

While political violence and the bloody civil war of the 1980s have all but dissipated, everyday violence and criminal activity continue unchecked. Given this bleak scenario, it is hardly surprising that the South African state is struggling to re-establish governance after apartheid. Neither is it surprising that ordinary citizens have lost faith in the capacity of the police and judicial system to stem the tide of lawlessness and violence that has swept across the country.

This crisis in governance is particularly evident in South African cities, where urban governance cannot rely on traditional liberal democratic notions of 'trusting citizens' and 'trustworthy' government, but rather on an urban social order built upon a combination of systems of punishment, discipline and security (Merry, 2001). In parts of Cape Town, this form of governance, which is constantly under attack from heavily armed and sophisticated crime syndicates, relies upon the micro-management of urban space. When it is successful, as in the historically white middle class parts of some South African cities, spatial governance usually involves a range of exclusionary practices, including the exclusion of 'offensive behaviour' and people, usually the poor and homeless, who look dangerous or disorderly.

In the absence of resources for surveillance cameras and private security 
beyond the fortified walls of middle class suburbs and shopping malls, the state continues to struggle to re-establish governance in 'unruly' black and 'coloured' townships.

When anti-apartheid planners and activists sought to render the townships ungovernable during the 1980s, they could not have anticipated how difficult it would be to re-establish governance after apartheid. Now the proverbial chickens have come home to roost and the ANC government is struggling to push back the tidal wave of crime, violence and lawlessness. By means of a case study that focuses on innovative attempts by the City of Cape Town Municipality (CCTM) to establish governance in Manenberg, a working class 'coloured' community, I will draw attention to the structural dimensions of the 'governance question'. This will involve locating the crisis in governance within the context of a shift to a service economy that has undermined traditional manufacturing and textile sectors that used to provide jobs to residents of working class communities such as Manenberg. Governance problems in places such as Manenberg, I argue, are exacerbated by these macroeconomic policy shifts.

\section{A governance crisis at the tip of Africa}

The spate of infant rapes in December 2001 shocked even the most hardened South Africans used to living in a society characterised by extraordinarily high levels of criminal violence and violence against women. ${ }^{3}$ South African citizens increasingly call on the post-apartheid state to adopt tougher measures to combat crime, including the reintroduction of capital punishment. Meanwhile those disillusioned with lack of capacity of the police and judicial system have resorted to community policing strategies including gated communities, para-military rural commandos, neighbourhood watch structures and the formation of vigilante groupings such as PAGAD, Amadlosi and Mapogo. Despite populist calls for the reintroduction of the 'kangaroo courts' and people's justice of the 1980s, the ANC government remains committed to the rule of law and to liberal democratic principles and procedures of governance.

At first glance the chaotic and violent character of post-apartheid (un)civil society seems to conform to media and scholarly representations of African states and societies as fundamentally 'dysfunctional' and ungovernable. For instance, we have recently witnessed the emergence of a growth industry in academic accounts of 'kleptocratic', 'criminal' and authoritarian African states (Bayart et $a l, 1999)$. These scholarly representations of African states reproduce media stereotypes of Africa as a 'basket case' continent doomed to human disasters including famine, war, endemic corruption, coups, genocide, AIDS, and so on. The most recent expression of this academic trend has been the writings of François Bayart et al (1999) and others who focus on the bizarre and grotesque rituals of African state power and 'the politics of the belly' (Mbembe, 1992; Bayart, 1993). At times this literature appears to mimic the exoticism of traditional anthropological topics such as witchcraft. Most of these studies revel in these cultural and political 'pathologies' without locating such phenomena within the political economy of underdevelopment. It appears that the 'cultural turn' ushered in by the post-cold war hegemony of post-structural and postmodern theory has 
valorised a 'new exoticism' that focuses on witchcraft, kleptocratic states and criminal syndicates while obscuring any reference to the economic relations of underdevelopment and the more mundane material dimensions of everyday life in Africa.

It would seem that any understanding of the rise in occult and religious movements and criminal violence in post-apartheid South Africa requires locating these developments within the context of recent shifts in the economy. For instance, the loss of well over half a million jobs between 1994 and 2000, largely as a result of liberalisation policies and the shift to a lean neoliberal state ${ }^{4}$ has become a catalyst for the dramatic expansion of associational life and informal economies, including religious and occult movements, savings associations, lotto and pyramid schemes, international drug cartels and crime syndicates, anti-crime vigilante groups, informal taxi organisations, and so on (see Comaroff \& Comaroff, 1999; 2000). ${ }^{5}$

It will become clear in the Manenberg case study discussed below that the massive growth of gangs and drug trafficking in working class townships of Cape Town is indeed symptomatic of these broader political and economic processes. These post-apartheid developments cannot be understood without taking into account the impact of the introduction of the neoliberal 'contract state' characterised by privatisation, outsourcing, public-private partnerships (PPPs) and 'downsizing' and 'rightsizing' initiatives. Neither can state interventions in urban governance be understood without reference to shifts from manufacturing to service economies.

\section{How 'civil' is civil society in the 'liberated zones'?}

During the anti-apartheid struggle, terms such as 'civil society', 'community' and 'the townships' conjured up images of virtuous and heroic working class black and 'coloured' people resisting apartheid state repression. The progressive and democratic connotations attached to these conceptions of community were periodically called into question by the violence of 'kangaroo courts' (or people's courts), and the 'necklacings' and brutal slayings of alleged impimpis (informers). Nonetheless, the political actions of these communities were generally valorised and lionised by the anti-apartheid movement, as well as by the more liberal voices within the mass media and the international community. Such conceptions of 'community' as an unmitigated 'social good' have, however, come under scrutiny during the post-apartheid period. The undemocratic, illiberal and at times violent practices of chiefs, warlords and shacklords, as well as of community-based vigilante groups such as Mapogo, Amadlosi and People Against Gangsterism and Drugs (PAGAD), have drawn attention to the Janus-faced character of the politics of 'community' after apartheid. This has also drawn attention to the limits of the post-apartheid state's attempt to render the townships governable.

Numerous cases of 'mob justice' have been reported in the press in recent years. Newspaper reports on the stoning to death of suspected thieves and rapists by angry crowds of crime-weary residents of black townships draws attention to what is becoming increasingly commonplace. The following caption refers to one 
such vigilante killing in one of Cape Town's black townships: 'Gruesome justice ... Shocked residents stare in horror at the body of a suspected thief who was pelted with stones, attacked with sjamboks and everything the enraged members of the mob could lay their hands on' (City Press, 7 October 2001). The report noted that in less than a month three people had been stoned to death in separate incidents by angry crowds of residents in Cape Town's Philippi and Khayelitsha townships. From the perspective of the ANC government, these activities pose a serious challenge to liberal notions of democracy and the rule of law. The strongarm tactics and violent patronage politics of some community leadership structures-for instance, civics, Reconstruction and Development Program (RDP) forums, ward committees, street committees - have also compromised notions of democratic practice and citizen participation. Clearly, community-enforced forms of punishment and discipline are taking place alongside the kind of spatial governmentality characterised by high walls, guard dogs, private security companies, surveillance cameras and policed shopping malls.

During the height of the anti-apartheid struggle in the mid-1980s, the liberation movements and community-based organisations had sought to render the townships ungovernable and create 'liberated zones'. The post-apartheid period, however, has witnessed concerted efforts by the state to reassert spatial governance and control over what are now seen as 'unruly townships'. To this effect the ANC government and the Department of Safety and Security have actively encouraged the formation of Community Policing Forums as well as neighbourhood watches. The state's sanctioning of these community policing structures has largely been a response to government recognition that it does not have the capacity and resources to deal with the massive explosion of criminal and gang activities in South African cities (see Steinberg, 2001; Comaroff \& Comaroff, forthcoming) ${ }^{6}$ This shift to community policing can be seen as a form of 'outsourcing' of policing functions by a neoliberal state unable to address crime on its own. It also draws attention to the state's acknowledgement of the need to reclaim governance in poor communities.

The state has encountered countless problems in its attempts to 'reclaim the townships'. These problems include urban land invasions, high levels of crime and violence, and the non-payment of rental, rates and levies for water and electricity. One of the most serious problems faced by the state is how to deal with 'informal' and illegal activities that are increasingly sustained by a political economy of criminal syndicates and gangs involved in drug trafficking and other illegal activities. Working class communities are no longer the romanticised spaces of heroic resistance to apartheid. Instead, many of these poor communities have become unruly spaces of dysfunction and disorder from the perspective of the state. The case study below focuses on the attempts by the Department of Community Development (Devcom) of the City of Cape Town Municipality (ССTM or 'Council') to re-establish governance in Manenberg, a 'coloured' working class community classified as 'dysfunctional' by senior city officials. This was to be done through a variety of interventions, including the introduction of individual home-ownership, 'oil spot' strategies of policing and crime prevention, and the 'hardening' and protection of public facilities. In other words, significant aspects of the Council's intervention involved what Sally Merry 
(2001) refers to as 'spatial governmentality'.

The Manenberg case study suggests that communities with weak governance structures and poor policing capabilities can become a nightmare in which citizens are terrorised by warlords, shacklords and gangsters. It was precisely such a scenario that plagued Devcom's urban renewal programmes. Residents told me of the physical dangers involved in having to navigate competing gang territories to access trains, taxis and Council facilities such as schools, the clinic, the library or housing office (see Salo, forthcoming). The clinic, for instance, had to be relocated to a classroom in a Manenberg school because it was situated in the middle of a gang battlefield. It was therefore hardly surprising that the Council identified the re-establishment of governance in Manenberg as a priority. A Manenberg Task Team was established 'to address the precipitous circumstances that staff faced in delivering services with particular reference to Manenberg'. The task team was mandated 'to follow a course of action that ensures (1) staff safety and security (2) staff receive maximum emotional and psychological support, (3) that plans to ensure service delivery be put in place'. 'The attempt to secure Council facilities and create safe public spaces proved to be more difficult than was initially anticipated. Before proceeding to a detailed discussion of these governance issues, however, it is necessary to situate Manenberg within the broader socio-spatial order of the apartheid city.

\section{'Fortress LA' at the tip of Africa? Spatial governance after apartheid ${ }^{8}$}

The race and class divide between Cape Town's historically white inner city and southern suburbs on the one side, and the black and 'coloured' townships on the other, remains firmly intact in the new South Africa. By removing blacks and coloureds from multiracial working class inner city neighbourhoods such as District Six in the 1960s and 1970s, and relocating entire communities to outlying Cape Flats townships such as Manenberg and Gugulethu, apartheid planners created the racialised grids of the apartheid city. The relocation of communities to Council flats on the 'Cape Flats' represented a first wave of modernist social engineering. While this housing scheme was an integral part of apartheid segregationist planning, recent housing development schemes discussed below have been 'progressive' interventions aimed at reforming the social and spatial fabric of fragmented and 'dysfunctional' communities shattered by unemployment, everyday violence and the devastating legacies of the forced removals of the 1960s and 1970s.

The template of the 'postmodern', post-apartheid city could seamlessly settle upon the spatial order produced by this earlier wave of apartheid social engineering. In recent years the historically white, middle class parts of contemporary Cape Town have witnessed a massive expansion of gentrification, mega-developments, heritage and tourist sites, and spectacles of consumption such as the Victoria and Alfred Waterfront and the Cavendish Square, Tygervalley and Century City mega-shopping malls-cum-recreation centres. These relatively new spaces of capital investment contrast starkly with the poverty, wastelands, and desolation of the racially segregated black townships of the Cape Flats. These racialised geographies of post-apartheid Cape Town reproduce the spatial logic of 
capital under apartheid despite the dramatic political reforms of the 1990s. The black and coloured working classes remain trapped in places of extreme poverty located at a considerable distance from middle class (mostly white) centres of commerce, tourism and consumption. This socio-spatial divide is reproduced through investment strategies that tend to steer clear of the dangerous and desolate spaces of the Cape Flats ghettoes. A multi-million-rand surveillance and security sector ensures that these (mostly white) middle class neighbourhoods and shopping malls are defended against what is perceived to be a dangerous underclass 'Other'.

Since the April 1994 democratic elections levels of gang-related violence in working class neighbourhoods in the Cape Flats have escalated on an unprecedented scale. The dramatic growth in the mid-1990s of PAGAD vigilantism has no doubt contributed to the 'tit for tat' killings on the Cape Flats. During the first half of 1998 over 60 drug- and gang-related killings took place on the Cape Flats, contributing towards an undeclared war between gangs and PAGAD. ${ }^{10}$ The 'City Fathers' (sic) and tourist entrepreneurs panic every time this gang violence spills over into 'white spaces' of tourism and consumption. This has intensified the militarisation of city life through an architectural semiotics of 'defensible space', thereby transforming Cape Town into a smaller version of 'Fortress LA' (Davis, 1990). In this process of fortification, control over defensible space becomes the major concern for both rich and poor. The urban poor of the Cape Flats lack the means to command and defend space, and generally find themselves trapped in dangerous spaces. ${ }^{11}$ These neighbourhoods are dangerous precisely because the need continuously to appropriate and defend space tends to result in the violent expulsion of unwanted elements, for example enemy gang members and outsiders. As David Harvey reminds us:

Fine-tuned ethnic, religious, racial and status discriminations are frequently called into play with such a process of community construction. Since ownership of even the basic means of reproduction (such as housing) is restricted, the main way to dominate space is through continuous appropriation. Exchange values are scarce, and so the pursuit of use values for daily survival is central to social action. This means frequent material and interpersonal transactions and the formation of very small scale communities. With [the formation of] community space, use values get shared through some mix of mutual aid and mutual predation, creating tight but often highly conflictual interpersonal social bonding in both private and public spaces. The result is an often intense attachment to place and 'turf' and to an exact sense of boundaries because it is only through active appropriation that control over space is assured. (Harvey, 1985: 261)

These low-income townships are also spaces in which the state perceives an urgent need to intervene, both to contain contagious social ills (from sex work to tuberculosis) and to pacify and control what are often seen to be violent, dangerous and unruly populations. The demolition and relocation of 'unhygienic slums' has been a standard measure of control over the 'dangerous underclasses' in South African cities and elsewhere in the world. According to Harvey (1985: 261), within this spatialised scenario the state tends to be seen by the underclasses as a repressive external agency rather than a resource that is controllable and beneficial. This spatialised class warfare continues to shape the post- 
apartheid urban landscape.

By contrast, the more affluent middle class can command space through spatial mobility and ownership of the basic means of reproduction, for instance houses and cars (Harvey, 1985: 261). In addition, the (mostly white) middle classes have the means to protect and fortify their suburban homes with vicious dogs, high walls, the latest alarm systems, and a proliferation of private security firms. Since the affluent are generally economically self-sufficient they do not need to command space through continuous appropriation and neither do they need street-level interpersonal relations and neighbourhood networks in order to meet their basic needs. Instead, their common interests and concerns generally revolve around a need to maintain the standards and property value of the built environment through a shared commitment to common conceptions of taste, tone, aesthetic appreciation, and symbolic and cultural capital (1985: 262). Since money provides access to the communities and necessary resources, these are less exclusionary communities (in terms of ethnicity and race) and tend to have diffuse and fluid boundaries. Given this scenario it is not surprising that the state is seen to be both beneficial and controllable, providing security and assisting in keeping undesirables out.

In this contemporary scenario of class warfare and the militarisation of everyday life, public space is destroyed in order to insulate, spatially and socially, the middle classes from undesirable Others. For instance, in new mega-structures and supermalls street frontage is designed in ways that consciously exclude the underclasses and street persons, and hawkers, strollers, and street people are often evicted from shopping malls by private security guards always on the lookout for non-consumers who might disrupt public consumption. Meanwhile those who live in South Africa's urban ghettoes find themselves socially and spatially imprisoned in repressive and bloody war zones where their security and safety can no longer be guaranteed by a state financially hamstrung by cutbacks brought about by neoliberal fiscal austerity measures. Given this privatisation of the policing of public places, it is only the wealthy who are able to afford the services of private security firms, while the poor remain easy targets of gang and criminal violence.

In Cape Town, tourism and the service industry have become key sectors within a 'mega city' economy that is both globally connected and internally divided into middle class white spaces of wealth generation, consumption and recreation, and black and coloured areas characterised by poverty and lack of resources. These socio-spatial legacies of the apartheid city are being reinforced by strategies of capital investment and accumulation whereby mega-shopping malls and recreation centres are located near middle class white suburbs and business centres at great distances from informal settlements and 'coloured' and black ghettoes. The location of these business investments serves to reinscribe the spatial logic of the apartheid city, and to subvert attempts by progressive planners to desegregate the city by bringing business investment and infrastructure closer to the historically black areas. In other words, while the 'city state' claims that it is committed to undoing and dismantling the racialised grids of the apartheid city, national and global capital undermines these plans by continuing to flow to white, middle class parts of the city. What this means is that 
the 'coloured' and African working class and the unemployed continue to be confined within under-resources spaces of poverty and everyday violence that are at great distances from the fortified middle class spaces of consumption, recreation, tourism and business. These processes are also reinforced by a state that is unwilling or unable to intervene in land markets, thereby reproducing apartheid planning practices that locate low-incomes black housing development at the southwest periphery of the city where land is cheapest. The following section discusses spatial governance and planning in the making and unmaking of the apartheid city.

\section{Spatial governance-the planner's fetish? The making and unmaking of District Six and Manenberg, Cape Town}

Manenberg was established as a 'Coloured township' following the 1960s and 1970s Group Areas Act-forced removals from District Six and other 'white' parts of Cape Town. The design of 'coloured' working class townships such as Manenberg was based on Ebenezer Howard's 'garden city' model, with blocks of flats, terraced and semi-detached houses, and a standardised architecture (Pinnock, 1989). Situated 15 kilometres from Cape Town's city centre, Manenberg is spatially isolated from adjacent black and coloured townships by means of highways, mainroads, railway lines and green belts and buffer strips (Jensen \& Turner, 1996: 83-85; Le Grange \& Robins, 1997). These socio-spatial legacies continue to have a profound influence on the shape of Cape Town after apartheid.

Planners of South African cities drew inspiration from Le Corbusier's 'Surgical Method' in their attempts to radically reconfigure the urban landscape. They appear to have shared Le Corbusier's faith in rationally conceived 'master' plans and urban designs that would create social order by means of 'proper' zoning of land use and the segregation of different social groups. In the name of social order and racial harmony, South African urban planners appropriated Le Corbusier's notion of planning as a rational, technical process that could be divorced from politics. It is worth quoting at length from Norman Hanson's introductory remarks made at the 1938 Town Planning Congress in Johannesburg:

It is possible to achieve this radical reorganization by drastic methods only, by a fresh start on cleared ground. This ruthless eradication directed towards a revitalizing process we haves, following Le Corbusier's lead, named the Surgical Method ... through surgery we must create order, through organization we must make manifest the spirit of a new age, (Hanson in Pinnock, 1989: 156, cited in Jensen \& Turner, 1996: 85)

This utopian faith in the capacity dramatically to transform 'disorderly' urban environments reflects the thinking of influential planners and architects going back to Baron Haussmann's mid-19th century renovation of Paris, and Ebenezer Howard's 'Garden Cities'. ${ }^{12}$ These ideas emerged in the 19th century in response to the problems of social disorder and threats to public health that came to be associated with the working class neighbourhoods of industrial cities of the British Victorian age. These planning interventions all share the assumption that it is possible radically to redesign the built environment in ways that improve the 
social fabric of 'dysfunctional' communities and neighbourhoods. In other words, planners believed, and continue to believe, that social behaviour could be strongly influenced by urban form. This case study draws attention to the limits of such 'physicalist' thinking, which continues to animate post-apartheid planning discourses. This will involve interrogating some of the underlying assumptions and urban planning in relation to questions of housing, built environment and citizenship and governance.

Starting from the premise that 'houses are much more than bricks and mortar', the following discussion examines the micro-politics and development discourses of housing and urban renewal in Manenberg following the 1999 tornado that swept through this coloured working class neighbourhood. Manenberg was described by City of Cape Town officials as 'dysfunctional' using indicators such as the extraordinarily high levels of criminal and gang violence, tuberculosis, substance abuse, the prevalence of teenage pregnancies and domestic violence. The Manenberg case study shows how housing interventions are often deeply embedded in ideological conceptions of 'development' that seek to create good governance and virtuous consumer-citizens out of the raw material of bricks, mortar and 'the unruly masses' ${ }^{13}$ It will become clear that, despite claims to the contrary, low-income housing and urban planning in South Africa have always been ideologically charged, and planners, policy makers, city managers and activists have engaged with urban development interventions in relation to these politically charged questions of race, ethnicity, citizenship and governance.

\section{Housing citizens in the Cape of Storms}

In August 1999 a tornado swept through the working class 'townships' of the Cape Flats in Cape Town. The destruction was particularly devastating in Manenberg, a 'coloured' neighbourhood known for its gang violence and for being the headquarters of Rashied Staggie's Hard Livings gangs. ${ }^{14}$ Manenberg constantly features in the media as a space of 'social pathology' and dysfunctionality, a representation that is reproduced through almost daily violence and gang killings. It is also associated with the highly militaristic and hierarchical prison gangs such as the '28s' and '26s' that have in recent years transformed themselves into sophisticated corporate structures connected to multinational drug cartels and crime syndicates such as 'The Firm', the Hard Livings and 'the Americans'. Drug trafficking, alcohol sales and distribution, gun-running, taxis and sex work are the major sources of revenue of this multibillion-dollar industry. With its extremely high levels of unemployment and poverty, Manenberg has become a ripe recruiting ground for the foot soldiers of the drug kingpins, the merchants and hitmen.

It was within this scenario that the ССТM planners, policy makers and senior managers identified Manenberg as one of Cape Town's six 'zones of poverty' that required 'special treatment'. ${ }^{15}$ The devastation unleashed during the tornado provided a unique opportunity to intervene in the social fabric and spatial design of Manenberg. A CCTM senior manager was quoted in the press as saying that the tornado was a godsend, as the destruction of blocks of Council flats controlled by the gangs would allow the Council to redesign the social fabric and built 
environment from scratch. The Devcom in the City of Cape Town (CCT) $)^{16}$ was responsible for the implementation of the tornado rebuild and urban regeneration programmes in Manenberg. In line with statutory development frameworks, CCT defined its major tasks as: (1) to re-establish governance in a gang-ravaged part of Cape Town; (2) to bring marginalised citizens into the mainstream market economy; and (3) to create the conditions for citizen participation in everyday political life (Vawda, personal communication; see also Chipkin, forthcoming).

One of Devcom's key strategies was to use individual ownership of lowincome houses as a means towards rebuilding moral and political community and breaking the stranglehold of gangs that controlled many Council rental flats ('Courts'). A key element in this strategy was to replace rental housing with individual home ownership. Council flats were perceived to reproduce the conditions of welfare dependency that contributed towards the disintegration of the nuclear family, which was deemed responsible for systemic social problems in Manenberg. Devcom's line of argument was that the Manenberg community was 'dysfunction' because family units tended towards disintegration and were therefore unable to socialise youth into adulthood (see Chipkin, forthcoming; Salo, forthcoming). In other words, Devcom's task was to create the conditions for 'proper' governance and citizenship in what was deemed to be a 'dysfunctional' community.

In attempting to combat the gangs and Manenberg's social problems, the Council drew on the purportedly positive attributes of individual home ownership. This was seen to be part of a strategy to help poor and working class citizens break out of a 'culture of poverty' and dependency that was perceived to be reproduced through rental housing, which in turn was seen to be part of an apartheid-created state welfare system. In addition, senior city managers argued that $90 \%$ of tenants of the Council flats were in arrears with their rental payments, ${ }^{17}$ and gangs often controlled access to the flats through patronage networks. In addition, key policy makers and senior managers within the Council argued that home ownership and the creation of a secondary housing market would draw poor people into the mainstream economy by assisting them to gain access to financial credit. It would also encourage home owners to contribute towards the improvement of their neighbourhoods, thereby increasing the value of their property. It was also envisaged that home ownership would strengthen the positive parenting role of the nuclear family, and in particular of female household heads. The latter were identified as socially responsible citizens-the economic and moral backbone of the community-who consistently paid the Council for the services they consumed (Vawda, personal communication).

The ANC Council attempted to re-establish governance as a necessary condition for citizen participation in public life in Manenberg. However, rather than resorting to a conventional policing solution to Manenberg's governance crisis and social problems, Devcom sought to address these problems by creating the conditions for the participation of marginalised citizens and poor communities in the mainstream economy and public domain. This objective was to be achieved through a variety of Council interventions in Manenberg, including ensuring safer access to Council facilities such as libraries, clinics and the housing office. Devcom Director Ahmedi Vawda argued that large numbers of Manenberg 
residents were involved in daily interactions with Council officials in the clinics, libraries and housing offices, and that these interactions were crucial for reestablishing governance. Yet during 1998 gang violence in Manenberg had resulted in the closing down of all Council facilities for extended periods. This ongoing situation of gang violence and disruption undermined the Council's developmental initiatives.

Other Council interventions included the 'hardening' of Council buildings to protect traumatised staff exposed to daily gang violence. Council planners also attempted to create safer public spaces and secure flat courtyards by means of walls and barriers that functioned as obstacles to the free movement of 'strangers' into flats and housing estates. In addition, in attempting to bring local government 'closer to the ground', Devcom helped establish area-based management systems whereby senior СCTM managers engaged directly with community leaders and local residents on Area Coordinating Teams (АCTs) that were responsible for conveying information and development priorities and plans to senior management structures and vice versa.

\section{Spatial warfare on the frontline}

The fieldwork for this paper took place at a time of serious crisis in Manenberg. The devastation of the August 1999 tornado had left hundreds homeless, and gang violence was on the increase. By November 2000 seven Manenberg children had died in the crossfire as a result of gang shootouts in the area. In addition, as a result of many years of unrelenting gang shootings and violence, the Council staff at the libraries, clinic and housing offices were suffering from acute forms of psychological trauma and stress disorder. A City of Cape Town Community Development Report, dated 3 February 1998 stated that 'there is a potential collapse of service provision in libraries, child care, health and housing in Manenberg, [and] gang violence is having a direct impact on service delivery'. The report went on to call for 'urgent attention and a course of action to physically protect staff and ensure emergency support is available'. This resulted in the 'hardening' of the library, clinic and housing office buildings at the cost of hundreds of thousands of rands. Meanwhile, many Council staff who were receiving trauma counselling were unable to cope with the extraordinarily high levels of stress and everyday violence in Manenberg. In addition, despite the fortification of Council buildings, in early 2000 the housing office and clinic, which were situated in the nerve centre of Hard Livings territory, were relocated to safer territory. The relocation in turn led to accusations from residents and from NGO and Community Based Organisation (Сво) representatives that the Council was more concerned about its buildings and its staff, who were virtually all non-residents of Manenberg, than about the ordinary residents who had to face these harsh conditions of everyday violence on an ongoing basis.

The local politics surrounding the closure and subsequent relocation of the clinic was extremely volatile. At numerous community meetings, residents and civic activists complained vociferously about the closure of the clinic. Council representatives were told that the elderly and sick now had to walk greater distances through dangerous rival gang territories to get to the relocated clinics. 
In response, staff mobilised their union representatives to convince the Council that their hazardous work conditions constituted a violation in terms of labour legislation. Clinic staff brought 'Sydney', a hitman for the American gang, to a community meeting to convince Dr Ivan Toms, a senior manager in the health services, that his staff were in serious physical danger if they went back to the original clinic site. Sydney told Dr Toms and others present at the meeting that 'I shoot at the clinic everyday. You can't take the staff back there. They're not safe.'

The Director of a Manenberg-based NGO understood the controversy surrounding the clinic to be the result of the fact that the clinic staff were regarded by gangsters and residents as outsiders: 'They've isolated themselves from the community. They are fearful of these people and act superior towards them. They tend to be arrogant and look down on residents. This makes them targets for abuse and intimidation. Municipal workers, the garbage collectors and so on, walk through Manenberg everyday and they don't encounter the same problems. Its all about class, status and attitudes. ${ }^{18}$ In other words, the social distance of Council staff from the community has bred local animosity towards them. From the perspective of the Council, however, there was a legally defined obligation to do everything in its power to protect intimidated and traumatised clinic, library and housing office staff.

Devcom's Ahmedi Vawda envisaged the provision and upgrading of community facilities such as libraries, community centres and computer laboratories as a central component of a strategy aimed at diverting youth from the dangerous streets to the safety of learning environments. This was perceived by Vawda to be in line with Cape Town's urban development strategy aimed at preparing youth to enter the new information economy with its growth sectors in IT and financial services. However, everyday violence in Manenberg presented serious obstacles to this strategy of promoting the growth of the knowledge industries. The excerpts from the daily diary kept by the Manenberg Library staff since January 1993 (see Figure 1) provide some indication of the levels of everyday violence that spill over into Manenberg's schools and libraries. Although I have arbitrarily selected a few months in 1993 and 1994, similar patterns and levels of violence are evident for all the years detailed in the diary (January 1993-August 2000). The chief librarian told me that he had started the diary initiative when he became convinced that official police statistics were hopelessly inaccurate and seriously underestimated the levels of violence and killings in Manenberg.

Given this context of daily gang violence, it is perhaps not surprising that Manenberg came to be represented in the media and in policy documents as a place of 'social pathologies', 'dysfunctionality', violence and trauma. What is less self-evident is how and why senior managers within the Council came to conceptualise individual home ownership and the creation of a secondary housing market as the panacea for these problems of social order and governance. What is clear, however, is that many Manenberg residents were themselves calling for the ANC Council to intervene more directly in eradicating gang activities and creating housing opportunities and the improvement of the physical environment. ${ }^{19}$

As was mentioned, this pressure on the Council to address the realities of gang violence also came from frontline Council staff who were thoroughly traumatised 


\section{JUNE 1993}

14: Borrower robbed in front of library.

17: Staff member's car was vandalised.

22: Borrower robbed at library entrance.

28: Stones thrown through windows.

\section{JANUARY 1994}

26: Heavy shooting, gun battle between gangsters and policemen station at police mobile station in front of library. Two staff members risked their lives to close the front door.

27: Shooting in front of library at $5.15 \mathrm{pm}$.

28: Mobile police station was withdrawn by police.

\section{FEBRUARY 1994}

1: Shooting in front of library-forced to close library. Managed to get staff out of the area safely.

4: Gang fight outside library. Number of shots fired (11.48am). Mobile police station returns-heavily barricaded.

7: Shooting at 5.12pm in front of library. Man shot through the head. Killed instantly.

8: Women caught in crossfire. Shot in chest.

11: Advised by police to clear out of the area-unsafe situation.

25: Man shot at shops next to library. Was brought to police caravan. Sat bleeding there.

28: Policeman stationed at the mobile police station. Urgently requested staff to phone for police back-up since shots were fired up the street and the situation was unsafe ...

\section{MARCH 1994}

1: Library closed.

\section{JUNE 1994}

13: Staff return.

15: Library reopened after almost four months. Stones thrown against windows.

28: Heavy stone throwing.

29: Stone throwing continues ...

FIGURE 1. Excerpts from the Manenberg Library diary.

by their experiences of everyday violence. A Community Development report to the СCT Executive Committee dated 2 March 1998 spelt out the implications of the 'Manenberg Crises':

There is a potential collapse of service provision in libraries, child care, health and housing in Manenberg ... The gang violence in the township (which often spills over into the adjacent townships) is having a direct impact on the service delivery locations. It has disrupted the provision of services, placed staff lives in danger and is cause for distress amongst staff such that they are traumatized, unable to work and, in instances, not wanting to return to work. It requires urgent attention and a course of action to physically protect staff [and] ensure emergency support is available ... The situation in Manenberg and Hanover Park has reached a dangerous 
point where the very existence of law and order, good governance, a stable social environment and healthy working conditions have all but become impossible. ${ }^{20}$

Another сст Report drew attention to the 'sporadic gunfire' near the housing office during the month of April 2000. Despite almost daily shootings outside the housing office, it was open for most of the month..$^{21}$ It was within this context of daily violence that the Council decided to relocate the housing office and clinic. These serious threats to good governance, service delivery and safety and security led to a variety of Council interventions including the 'hardening' (fortification) of Council premises and identification of safe rooms, the development of communication networks (the 'buddy system') and trauma support for staff, the provision of bleepers and panic buttons, the provision of safe transportation of Council staff in and out of the area, and the development of risk management strategies, disaster management, alternative service provision and contingency plans in case of the breakdown of services as a result of gang violence..$^{22}$ Given the extraordinary levels of everyday violence in Manenberg, and the Council's responsibilities to protect its staff as well as ordinary citizens, the Council was clearly obligated to intervene in order to 're-establish governance'. However, Devcom's 'hardening' of Council buildings and the use of housing delivery to re-establish governance failed adequately to take into account the structural dimensions of a political economy of drugs and gang violence. So what kind of state and state intervention would have been necessary to reestablish governance in Manenberg?

\section{States of surveillance and control?}

James Scott's highly influential book, Seeing Like a State, published in 1998, attempts to understand statecraft as a process of rendering populations 'legible'. Scott argues that this has been achieved through a series of disparate state practices of surveillance and control, including sedentarisation, the creation of permanent names, the establishment of cadastral surveys and population registers, the invention of freehold tenure, the standardisation of language and legal discourse, the design of cities and the organisation of transportation. These practices have functioned 'as attempts at legibility and simplification'.

Much of early statecraft seemed similarly devoted to rationalizing and standardizing what was a social hieroglyph into a legible and administratively more convenient format. The social simplifications thus introduced not only permitted a more finely tuned system of taxation and conscription but also greatly enhanced state capacity. They made possible quite discriminating interventions of every kind, such as publichealth, political surveillance, and relief for the poor. (p 3)

Scott concludes that these state interventions tend to fail because they are designed and implemented as top-down, standardised packages that ignore the complexity of informal social processes. Nonetheless these state technologies of surveillance and control appear to have had some successes in the advanced capitalist countries of the North. It is less clear, however, to what degree they have been effective in colonial and postcolonial countries in the developing world. 
This question is taken up in Timothy Mitchell's Colonizing Egypt (1998). Mitchell draws on a Foucaultian analysis of the modern disciplinary state to investigate new forms of colonial state power based on the re-ordering of space and the surveillance and control of its occupants. According to Mitchell, the Panopticon and similar disciplinary institutions were developed and introduced in many instances not in France and England but on the colonial frontiers of Europe, in places like Russia, India, North and South America, and Egypt. Nineteenth century Cairo, for example, provided an excellent opportunity to establish a modern state based on the new methods of disciplinary powers, including military reform, the supervision of hygiene and public health, compulsory schooling, agricultural reforms involving controls over movement, production and consumption, and the rebuilding of Cairo and other Egyptian towns and villages to create a system of regular, open streets that were conducive to surveillance and control (Mitchell, 1998: $\mathrm{x}$ ). ${ }^{23}$

James Scott, Tim Mitchell and Foucaultian analyses of development discourse more generally (see Escobar, 1995; Ferguson, 1990), tend to emphasise the omnipotence of state discourses and the docility of subject-citizens, who appear in these writings as passive victims of an all-encompassing modern state apparatus. The Manenberg case study, however, draws attention to problems with Foucaultian analyses of disciplinary institutions and the surveillance state. Everyday life in 'unruly' places such as Manenberg draws attention to the limits of state power and control, for example by highlighting the agency and resistance of citizens who are exposed to state interventions. In other words, these are anything but the docile subject-citizens assumed in much Foucaultian analysis.

The Manenberg case study draws attention to the limits of attempts by senior city managers and planners to use individual home ownership and urban spatial design to achieve the following objectives: (1) to re-establish governance and create law abiding citizens, thereby undermining the power of the gangs; (2) to break down 'social pathologies' and a 'culture of poverty' reproduced by high levels of unemployment; and (3) to intervene in the socio-spatial grids of the apartheid city in order to promote integration between Manenberg's 'coloured' population and black African residents of the adjacent township of Gugulethu.

Devcom strategists assumed that it would be possible to re-establish governance and improve the neighbourhood through a combination of individual home ownership and urban spatial design innovations. For instance, one of the problems identified with Manenberg's flats was that gangsters had open access through the courtyards, and gangsters chased each other through the courtyards on a daily basis. Walls and barriers were subsequently built around existing flat courtyards and new houses in order to limit access to outsiders. The planners' over-emphasis on physical form and spatial design, however, did not take into account the structural dimensions of the political economy of gang violence. Neither has this spatial design approach countered the socio-cultural dimensions of gang culture by addressing the "distinctive milieus for social interaction from which individual [gang members] derive their values, expectations, habits and states of consciousness' (Harvey, 1985: 118). ${ }^{24}$

These ССтм senior managers and planners believed that home ownership and spatial design alone could make a significant contribution towards re-establishing 
governance in Manenberg. But the Cape Town Housing Company (СТHC) scheme that was introduced in Manenberg was challenged by community activists, poorer residents and illegal sub-tenants and backyard shack-dwellers who were initially excluded from the scheme. ${ }^{25}$ The liberal individualist conception of the 'consumer citizen' (or 'citizen-consumer') clashed with deeply embedded community structures, neighbourhood and gang networks, and communal solidarities of residents, especially the poorer sections of the community. Community activists claimed that the Council was undermining community interests and 'community-consciousness'. The Council's attempt to create a 'new citizen identity' through home ownership was bound to encounter obstacles given the political economy of gangs, drug trafficking and everyday violence in Manenberg. ${ }^{26}$

\section{The structural dimensions of gang violence and 'dysfunctional' communities}

Within this scenario of high unemployment, poverty, violence and gangsterism in Manenberg the Council decided to replace the badly damaged Council flats with individually owned homes. This 'rent-to-buy' housing scheme aimed to use the 'positive social values' attributed to individual home ownership as a means of overcoming the social pathologies associated with Council rental housing and public housing estates in the Cape Flats. In terms of ССТM thinking, home ownership would facilitate the creation of a secondary housing market and the improvement of the built environment, thereby acting as a catalyst for urban regeneration programmes. In other words, it was believed that housing development could contribute towards improving the built environment and the social fabric and moral economy of Manenberg. The ССТM scheme was not only concerned with the moral economy. It was also widely believed that the establishment of a secondary housing market would kick-start a cycle of upward mobility through the creation and expansion of poor people's investment in their asset base (Edgar Pieterse, personal communication). This would in turn stimulate the local economy and increase the rates base. ${ }^{27}$ In other words, along with safety and security projects and economic development programmes, housing would become a key catalyst for a systemic programme of urban regeneration.

The following CCTM definition of the problem, terminology and principles for urban renewal and regeneration highlights the approach of Devcom:

Urban renewal is understood to be about changing the physical environment, whereas urban regeneration implies a rebuilding of both the physical and social environment. It is imperative that we have a common definition and understanding of urban regeneration and its related strategies. Where such strategies need to be implemented there must be a community understanding of the following: the physical environment; the social factors and degree of dysfunctionality within a particular community; the service delivery environment, what resources are available and how it is being used ... The following principles should provide the foundations of an urban regeneration programme: rebuild community confidence; re-establish governance; focus on integrated co-operative governance, establish a service delivery strategy via Area Co-ordinating Teams, establish Area Based Project Management ... recognize livelihood strategies in communities in con- 
tributing to local development. (Community Development Report, Urban Regeneration, 24 October 2000)

One of the major problems with the Council's housing model and the urban renewal programme was that these were predicated upon a liberal individualist conception of the 'consumer citizen' (or 'citizen-consumer') that clashed with locally embedded community networks and communal identities, especially among the illegal sub-tenants, backyard shack-dwellers and poorer residents who were initially excluded from the scheme. The Manenberg Disaster Committee (MDC), a civic organisation that emerged in response to the 1999 tornado, challenged the Council's housing scheme by claiming that it ran counter to community interests. In other words, the Council's attempt to create a 'new citizen identity' through home ownership came to clash with civic activists claiming to defend neighbourhood solidarities and the interests of poor and marginalised residents of Manenberg.

The Council's Devcom encountered numerous obstacles in its attempts to introduce urban renewal by re-establishing governance and incorporating marginalised citizens into the mainstream economy and political life. It appears that the Council's senior managers and planners did not properly understand the political and economic structures that reproduced poverty, crime, violence and 'dysfunctional' patterns of behaviour associated with places like Manenberg. In other words, Council management and officials failed fully to understand and acknowledge the structural and institutional obstacles to attempts to re-establish governance and incorporate 'the poor' into the market economy.

For decades the Council has been dominated by engineers and planning technocrats for whom the provision of basic services (eg water, electricity and refuse collection), rather than community development, has been the Council's core business (Vawda, personal communication). This technicist perspective, however, failed to fully appreciate the social and political implications of Cape Town's drug economy, gang violence and unemployment for governance and service delivery. As a result, the Council was unwilling and unable to address the impact of growing unemployment resulting from recent shifts from a traditional manufacturing economy to a service sector economy focusing on tourism, the film industry and IT and financial services. ${ }^{28}$ Instead of addressing the implications of these job losses, ССТм senior management and the private sector celebrated the fact that, in the first 10 months of 2001, R7 billion had been poured into huge building projects in central Cape Town (Sunday Times, 11 November 2001). This fitted in with private sector and Council fantasies of establishing Cape Town as a globally competitive service economy replete with international convention centres and five-star hotels, business and recreation centres and mega-shopping mall developments. None of these developments is likely to provide significant numbers of jobs to people living in Manenberg and other working class Cape Flats townships.

As a result of these recent economic shifts, the formal economy is increasingly unable to provide employment to poorly educated and unskilled residents of neighbourhoods such as Manenberg. By contrast opportunities do seem to exist for those willing and able to participate in the violent economies of drug 
trafficking, protection, extortion, crime, sex work and the taxi industry. While most gang members in Manenberg comprise young men who spend their days fighting over women and vaunting their masculine pride and reputations for toughness, their activities are tied to the recruitment of dealers and merchants into massive drug operations that are based in other parts of the city, for instance Greenpoint and Sea Point. In addition to these very real economic opportunities, the lure and glamour of gang culture is also fuelled by urban mythologies surrounding notoriously wealthy and powerful Hard Livings gangsters such as the Staggie brothers. Notwithstanding attempts by the Council to re-establish governance and spatial governmentality through the creation of safe public spaces, these initiatives continue to be undermined by this political economy of crime, violence and unemployment.

\section{Conclusion}

This article has argued that attempts by the city authorities to re-establish governance in Manenberg failed because of the inability of the state to address growing unemployment in an urban environment characterised by a thriving drug and gang economy involving sex work, crime, protection syndicates, and a booming tax industry associated with violence and gang control over transportation routes. This failure to re-establish governance occurred despite concerted efforts by city planners and officials to spatially engineer the built environment through the establishment of individual home ownership housing schemes and the 'hardening' and protection of key government buildings such as clinics.

The contestation between the state and gangs over control of space in Manenberg is part of a broader process in terms of which current investment strategies and urban development schemes have avoided poor areas of the Cape Flats, thereby reproducing the socio-spatial inequalities of the apartheid city. Despite the many well intentioned interventions by the city authorities, the socio-spatial logics of the apartheid city persist. Investors and businesses continue to gravitate towards the well policed, historically white, middle spaces of the city. These parts of Cape Town have indeed been incorporated into a representation of Cape Town as a globally competitive, multicultural city driven by the tourism industry and the IT and financial service sectors. There are, however, at least two other sides to Cape Town. One side is the 'fortress city' of middle class neighbourhoods characterised by gated communities, neighbourhood watches, vigilantes, private security companies, surveillance cameras, high walls and barbed-wire fences. The other is the urban ghettoes of the Cape Flats, characterised by racialised poverty, crime and violence.

Post-apartheid Cape Town remains a deeply divided city, with middle class enclaves fortified against black African and 'coloured' townships that are perceived as dangerous 'no-go zones'. It is within this highly polarised urban landscape that spatial governmentality has become such contested terrain. New forms of spatially organised crime control that characterise contemporary Cape Town include a proliferation of gated communities, and numerous initiatives aimed at creating prostitution- and crime-free zones through the use of closed circuit television cameras and 'zero-tolerance policing'. Even graffiti artists have 
found themselves the targets of this new urban war against 'grime'. As Merry (2001: 16) points out, 'these are all examples of new regulatory mechanisms that target spaces rather than persons [and that] exclude offensive behaviour rather than attempting to correct or reform offenders'. The urban renewal programme introduced in Manenberg following the destruction caused by the tornado in 1999 represented such an attempt to regulate space through architectural design, individual home ownership and security devices. These initiatives were meant to complement modern disciplinary penality but were vastly different in their logic and technologies (Merry, 2001). The Manenberg case study suggests that this attempt at spatial governmentality failed to dislodge the deeply embedded gang structures and activities that have been fuelled by the shift of the Western Cape economy from traditional manufacturing to a service and tourist-driven economy. This troubling account from the Cape of Storms is yet another global warning about the rough weather that awaits city planners and officials who uncritically embrace the cyber vision of a globally competitive IT-driven Silicon Valley economy at the tip of Africa.

\section{Notes}

This article is based on research funded by Isandla Institute and the Community Development Unit of the City of Cape Town under the Directorship of Ahmedi Vawda. For their helpful comments, local knowledge, insights and creative criticism, I must thank Ahmedi Vawda, Bettina Von Lieres, Edgar Pieterse, Christoph Haferburg, Elaine Salo, Chris Giles, Christine Jansen, Russel Dudley, Joe Essak, Pete Van Heerden, Ivan Toms, Owen Munroe, Joel Bolnik, Firoz Kahn, Chris Tapscott and Ivor Chipkin. In addition, I owe special thanks to the numerous Manenberg residents and City of Cape Town officials who contributed generously during the research process. The first draft of this article was written in June 2000 at the University of Bergen, Department of Public Administration. I would like to thank my Bergen and University of the Western Cape colleagues for their insights and contributions during various discussions and presentations of this work.

The gated community syndrome is usually associated with 'Brazilianisation' rather than 'Californianisation'. This suggests that there is considerable scope for 'Southern', as well as 'Northern', comparisons and conceptualisations of spatiality and governance. There is already an extensive literature on the ways in which the political economy of neoliberalism is shaping these urban processes (eg social-spatial inequalities and racial polarisation) in post-apartheid South African cities (see Bond (2000)). There is also a burgeoning South African urban studies literature that includes Bremner (1994), Bond and Tait (1997), Crankshaw (1996), Hindson et al (1994), Huchzermeyer (1999), Mabin (1991, 1992), Smith (1992), Parnell (1991), Swilling et al (1991), and Tomlinson (1994). See chapters on urban citizenship and governance in Cape Town by Ivor Chipkin, Rafael Marks, Elaine Salo, Andrew Spiegel, Shannon Jackson and Clifford Shearing and Jennifer Wood in Robins (2003, forthcoming). Other recent studies on Cape Town include Vanessa Watson (1995), Spiegel et al (1996, 1999) and Robins (2000).

Cape Town's strategic surveillance unit, which operates the closed circuit television (CCTV) cameras used to fight crime in the city centre and on the N1 highway, has recently begun to expand its operation to include public places and roads in high-crime areas of the Cape Flats such as Manenberg. The CCTV crime unit provides the police and city traffic department with visual information on crime, informal trading, protest marches, advertising billboards and fire hazards. According to Ian Neilson, the Cape Town unicity's executive councillor for safety and health, the CCTV system will contribute towards the process of developing Cape Town as a model global city (Cape Times, 24 January 2002). Some 25000 South Africans are killed annually as a result of violent crime, and South Africa is regarded as being the murder and rape capital of the world. Following dramatic reporting of infant rapes throughout the country in December 2001, President Mbeki called for a meeting with religious leaders to discuss the breakdown in the moral fabric of the nation, while the former president, Nelson Mandela, reiterated the widely held view that these infant rapes were linked to misguided beliefs about cures for AIDS. This development followed the rise in the incidence of rapes of young girls by men who believed having sex with a virgin could cure them of AIDS. Others ascribed these crimes to a 
complete collapse of the country's moral fibre, itself attributed to the violent legacies of apartheid, massive unemployment and poverty and a host of other factors (Sunday Times, 9 December 2001). Sunday Times journalist Sechaba Ka' Nkosi noted, for instance, that the profile of the mothers of the raped infants was the same: poor, largely uneducated and single. Their ages ranged from late teens to early 20s. They were usually unemployed. The perpetrators' profile was similar: unemployed, young and known to the mothers (Sunday Times, 9 December 2001). Yet again there was a loud call from 'the public' for the reintroduction of the death penalty, for tougher jail sentences and for communities to be allowed to take the law into their own hands. The state was perceived by most citizens as unable to control spiralling crime and violence.

The latter half of the 1990s witnessed a shift from the Reconstruction and Development Programme (RDP), with its state-centric approach to development, to the 'neoliberal' Growth, Employment and Redistribution (GEAR) strategy. Patrick Bond (2000) suggests that the shift to GEAR was largely a reaction to the perceived failure of the state to drive development and reconstruction during the 1990s, and that this led to GEAR's acknowledgement of the central role of the private sector in job creation and development. As a result, GEAR promotes a more modest role for central government as facilitator of development through public-private partnerships, privatisation, contractual outsourcing and the decentralisation and devolution of competence to local government. It remains to be seen how these procedures will affect citizens' ability to access state resources and service delivery.

The global reach of neoliberalism - and the retreat of the developmental state-has also generated more 'conventional' forms of associational life in South Africa, including the globally connected NGOs, Transnational Advocacy Networks (TANs) and lobby groups. Treatment Action Campaign (TAC), for example, successfully challenged international pharmaceutical companies and government AIDS policies through the strategic use of the courts and national and international campaigns. In addition, numerous cyber-connected environmental, media and anti-arms trade organisations have entered into this newly emerging post-apartheid public sphere and global civil society.

At a Mowbray community policing forum, 14 November 2001, Ministry of Safety and Security, Hennie Bester, spoke of the logistical headache the South African police have had to deal with in attempting to fight ordinary criminal activity while having to commit resources to ongoing problems of urban terror, taxi violence, gang drug trafficking and turf wars, criminal syndicates, and so on.

City of Cape Town, Manenberg Task Team Project Definition Report, Draft 1998-04-03, p 4.

Parts of this section appear in Robins (2000).

An article in the Cape Times on 5 March 1998 entitled 'Cameras to watch over you: huge waterfront security shake-up' described the multi-million-rand security upgrading initiative following a shoot-out between two shoplifters and security guards at Cape Town's Waterfront shopping mall. Directly opposite this front-page story was a large colour photograph of a grieving coloured woman, her eyes blood red from crying. Her teenage son had been killed in a triple assassination at Clarke's Estate, a coloured neighbourhood in the Cape Flats. The caption read: 'Violent death is nothing new in this gang-ridden areas, but the triple killing has shocked the community ... The police say they died in Americans' gang territory'. Two weeks later four young men were killed at the entrance to the Waterfront in what police described as yet another gang assassination. More surveillance cameras were immediately installed at the Waterfront entrance and security was stepped up. The fear of the spill-over of gang violence from the Cape Flats into the Waterfront prompted immediate action.

10 This violence has over the past few decades become naturalised and normalised through essentialist discourses on a purported coloured predisposition towards violence and gangsterism. PAGAD and representatives of community police forums sought to displace this normalising discourse by drawing public attention to police corruption, inefficiency, inadequate resources, and the state's alleged indifference to the bloodbath on the Cape Flats.

11 For some of my University of the Western Cape (UWC) students who live in black and coloured townships of the Flats, the safe spaces of recreation are mostly the malls in formerly white parts of the city; however, they often cannot afford the transport costs of a taxi to the Waterfront or Cavendish Square. The UwC students I interviewed, and who live in conflict-prone townships on the Cape Flats, expressed powerful feelings of isolation, claustrophobia and incarceration in dangerous and bleak spaces. This was especially the case for women, for whom the township streets can be hostile and threatening places dominated by aggressive men and dangerous gangsters. For many male students, who also experienced the township streets and shebeens as dangerous spaces, the only viable alternative places of recreation to the shopping malls were sports venues and staying at home to watch television and socialise with friends and family.

12 Ebenezer Howard's 'garden city' was not meant to be a suburb but the antithesis of a suburb. It was not a rural retreat but rather a synthesis or symbiosis between urban and rural: a compact garden city would have ample open space, a park at its centre, and tree-lined boulevards and gardens surrounding the housing. In its design the garden city shows a concern for amenity, pollution and resource conservation. Cultural and leisure facilities are located centrally, for example the central park. The 
legacy of Howard's ideas are green belts, protected agricultural land, low-density housing, industrial trading estates, shopping centres and neighbourhood facilities (Pile et al, 1999: 254).

13 A key feature of these interventions has been the social and spatial separation of the middle class from 'the poor', and the creation of the private space of the home within which the nuclear family could be nurtured and protected. According to Roger Silverstone (1997: 7; cf Pile et al, 1999: 31), this EuroAmerican suburban culture was, and continues to be, highly gendered. It is built around an ideology and a reality of women's domestication and confinement to household work and the private domain. Throughout Europe and North America, this suburban culture was buttressed by public policies, state resources and media images that attempted 'to resocialize women into the home, and into the bosom of the nuclear bourgeois family' (Silverstone, 1997: 7).

14 Staggie's Hard Livings gang is based in Manenberg and has over the decades become one of the most powerful crime syndicates, involved mostly in the drug trade, but it has also diversified into the sex work and taxi industries.

15 See сCт Community Development Report on Urban Regeneration, 24 October 2000. The Manenberg zone was identified as 'the worse [sic] off in terms of poverty and dysfunctionality'. The six zones of poverty included iSLP (Philippi, Crossroads, Nyanga and Browns Farm), Manenberg zone (Gugulethu, Hanover Park, Heideveld and Manenberg), Langa, Kewtown, Woodstock/Salt River and Mitchells Plain. The key social indicators for the Manenberg zone, Kewtown, Woodstock/Salt River and Mitchells Plain, included 'poor, high crime and dysfunctional'.

16 Sometimes I will use 'CCT officials' to refer to both Devcom and CCT officials. I do this because the Devcom team worked as part of a larger team that included СCT planners and officials from other CCT departments.

17 A Cape Town Unicity task team recently warned of a looming financial crisis, with the city authority's debt soaring to a record R2.4 billion-equal to almost $40 \%$ of the city's R9 billion budget. A report compiled by the city's credit control task team warned of debts rising by R700 million in 12 months and posing 'real risks to the city's financial integrity' (Cape Metro, Sunday Times, 4 November 2001). The report noted that, seven years after the end of the civic protests and rent boycotts against apartheid, "it is common knowledge that certain of our customers were encouraged not to pay municipal accounts for services rendered and that council and its predecessors have been involved in uphill battles to redress the consequences of those actions' (Cape Metro, Sunday Times, 4 November 2001).

18 Chris Giles, Director of Self-Help Manenberg, a local NGO, believes that the police are completely illequipped and inefficient and that governance in Manenberg requires blockades with soldiers similar to the situation in Northern Ireland. He believes that this could be done if there was the political will to deal with crime and violence. He suspects, however, that in many instances the police and politicians are colluding with the underworld druglords and criminal syndicates. Giles suggested that legalising drugs could bring the price down, and that this could contribute towards reducing the levels of violence associated with the protection of supply lines and turf wars. The Minister of Safety and Security, Hennie Bester, recently told residents of the Mowbray Community Policing Forum of the extraordinary profits generated by the trade in ecstasy.

19 Manenberg residents interviewed in 2000 by Christoph Haferburg and UWC post-graduate students called upon the Council to build more houses for residents who have been waiting on housing lists for 10-15 years. Respondents also insisted that the Council should repair its buildings and rental stock and hand over Council houses and flats to tenants who have been paying rent for many years. Residents also claimed that, while the Council provided basic services, it needed to do more to clean the streets and Council housing in the area. The most frequent demand from residents was that the Council needed to do more to eliminate gangsterism in Manenberg: 'The Council is too passive with regards to complaints of the residents here. We have complained about the shebeens but the Council has done nothing so far. The Council have [sic] to bring discipline here in Manenberg. The police must patrol the place properly ... The place is full of gangsters. They must be gotten rid of. The shebeens must be closed ... The Council must be more visible to the community. Drugs are affecting the community badly ... The neighbourhood watch must come and patrol the area to protect us in Sherwood Park ... The Council must wipe out the gangsters.'

${ }^{2}$ Report, Community Development, 1998-02-03, The Executive Committee, Manenberg Crisis.

${ }^{21}$ City of Cape Town, Community Development 'Status Report: Manenberg Crisis' (2000-04-14).

22 City of Cape Town Manenberg Task Team Project Definition Report. Draft 1998-04-03.

23 Mitchell (1998) analyses these innovations as the vehicles of a modernist metaphysics that generates the modern experience of meaning as a process of representation ( $\mathrm{p}$ xiii). Mitchell's analysis of world exhibitions and urban planning in colonial Cairo focuses on the 'modernist experience of the real' produced by the generation of what seems an unproblematic distinction between reality and its representation.

${ }^{24}$ The CСТM's attempt to undermine these community-based gang cultures can be seen as part of a more 
general process whereby 'community-consciousness' is first made through residential differentiation (along class, ethnic and race lines) and then destroyed in the name of the national interest and capital accumulation (Harvey, 1985: 123). As David Harvey notes, 'Community consciousness with all of its parochialisms, once created becomes deeply embedded, and it becomes just as difficult to piece it together in a configuration appropriate to the national interest (as perceived from the standpoint of capital accumulation) as it is to transform it into a class-consciousness antagonistic to the perpetuation of the capitalist order. In order, therefore, to maintain its own dynamic, capitalism is forced to disrupt and destroy what it initially created as part of its own strategy for self-preservation. Communities have to be disrupted by speculative activity, growth must occur, and whole residential neighbourhoods must be transformed to meet the needs of capital accumulation. Herein lie both the contradictions and the potentials for social transformation in the urbanization at this stage in our history' (Harvey, 1985: 123).

${ }_{25}$ Advocates of both the new public management and the community participation models claim to depart from the 'traditional' public sector model, which is seen to be highly rule-bound and hierarchical and built around centralised power and authority. During the 1990s the traditional model of bureaucracy, inherited from the apartheid era was vigorously attacked by both the Left and the Right for being wasteful, inefficient, hierarchical and outmoded. In addition, it was seen to be incapable of dealing with complexities, uncertainties and contingencies by virtue of being preprogrammed through inflexible, standardised procedures. It was within this management policy scenario that the ССТM embarked upon a public-private partnership low-income housing development scheme in Manenberg.

26 During the French Revolution it was possible to 'liberate individuals' and create a 'new universal citizen' by eliminating all existing identities. According to Manuel Castells, France is probably the only country in the world that has been able to achieve this extermination of identities other than the French identity. According to Castells, 'the French model became the most effective model in building the citizen identity, which is an identity which is abstracted from any other historical group except the state, the democratic state' (2000: 8).

27 ССТ Community Development Report, Urban Regeneration, 24 October 2000.

28 This was particularly evident in the garment industry where, despite a boom in clothing and textile exports in 2001, the SA Clothing and Textile Worker's Union (SACTWU) reported the loss of an average of 1400 formal jobs a month. Factory closures in the clothing sector, Cape Town's biggest employer, wreaked havoc for Manenberg women traditionally recruited into the garment industry. In the first 10 months of 2001, 19 companies shut their doors resulting in the loss of 2249 jobs in the clothing sector (Cape Argus, 29 October 2001). As the Cape Argus reported, 'Thousands of jobs lost in city rag trade exodus to seek cheap rural labour.'

\section{References}

Bayart, JP (1993) The State in Africa: The Politics of the Belly (London: Longman).

Bayart, JP, Ellis, S \& Hibou, B (1999) The Criminalization of the State in Africa (London: International African Institute and Oxford: James Currey).

Bond, P \& Tait, A (1997) The failure of housing policy in post-apartheid South Africa, Urban Forum, 8 (1), pp 19-41.

Bond, P (2000) The 1980s township housing boom, in: P Bond (ed), Cities of Gold, Townships of Coal" Essays on South Africa's New Urban Crisis (Johannesburg: Africa World Press).

Bremner, L (1994) Development and resistance. The lessons for the planners of Phola Park, Urban Forum, 5 (1), pp 23-44.

Caldeira, T (2000) City of Walls: Crime, Segregation, and Citizenship in São Paulo (Berkeley, CA: University of California Press).

Caldeira, T (1996) Building up walls. The new pattern of segregation in São Paulo, International Social Science Journal, 48 (1), pp 55-65.

Castells, M (2000) Globalisation, identity and the state. Social Dynamics-A Journal of the Centre for African Studies, University of Cape Town, 26 (1), Winter, pp 15-17.

Chipkin, I (forthcoming) 'Functional' and 'dysfunctional' communities: the making of ethical citizens, in: S Robins (ed), Limits to Liberation: Citizenship and Governance After Apartheid.

Comaroff, LJ \& Comaroff, J (eds) (1999) Civil Society and the Political Imagination in Africa: Critical Perspectives (Chicago, IL: University of Chicago Press).

Community Development Report, Urban Regeneration, City of Cape Town, 24 October 2000.

Crankshaw, O (1996) Social differentiation, conflict and development in a South African township, Urban Forum, 7 (1), pp 53-67.

Davis, M (1990) City of Quartz: Excavating the Future of Los Angeles (London: Verso). 
Escobar, A (1995) Encountering Development: The Making and Unmaking of the Third World (Princeton, NJ: Princeton University Press).

Ferguson, J (1990) The Anti Politics Machine: 'Development', Depoliticization and Bureaucratic State Power in Lesotho (Cambridge: Cambridge University Press and Cape Town: David Philip).

Harvey, D (1985) The Urbanization of Capital (Oxford: Basil Blackwell).

Jensen, S \& Turner, S (1996) A Place called Heideveld: Identities and Strategies among the Coloureds in Cape Town, South Africa. Publications from the Department of Geography and International Development Studies, Roskilde University, Denmark. Research Report No 112.

Le Grange, L \& Robins, S (1997) The Wetton-Landsdowne Road Corridor area: the Identification of Culturally Significant Places and Opportunities. South Africa.

Hindson, D, Byerley, M \& Morris, M (1994) From violence to reconstruction: the making, disintegration and remaking of an apartheid city, Antipode, 26 (4), pp 323-350.

Mabin, A (1991) The dynamics of urbanisation since 1960, in: M Swilling, R Humphries \& K Shubane (eds), Apartheid City in Transition (Cape Town: Oxford University Press).

Mabin, A (1992) Dispossession, exploitation and struggle: an historical overview of South African urbanisation, in: D Smith (ed), The Apartheid City and Beyond: Urbanisation and Social Change in South Africa (Johannesburg: Routledge/Witwatersrand University Press).

Mbeme, A (1992) The Banality of Power and the Aesthetics of Vulgarity in the Postcolony, Public Culture, 4 (2), pp 1-30.

Merry, S E (1981) Urban Danger: Life in a Neighbourhood of Strangers (Philadelphia, PA: Temple University Press).

Merry, S E (2001) Spatial governmentality and the new social order: Controlling gender violence through law, American Anthropologist, 103 (1), pp 16-29.

Mitchell, T (1998) Colonising Egypt (New York: Cambridge University Press).

Nederveen Pieterse, J (2000) Global Futures: Shaping Globalization (London: Zed Books).

Parnell, S (1991) Race, class, gender and home ownership subsidies in contemporary South Africa, Urban Forum, 2 (1), pp 21-39.

Pile, S, Brook, C \& Mooney, G (eds) (1999) Unruly Cities: Order/Disorder (London and New York: Routledge in association with The Open University).

Pinnock, D (1984) The Brotherhoods: Street Gangs and State Control in Cape Town (Cape Town: David Philip).

Pinnock, D (1989) Ideology and Urban Planning: Blueprints of a Garrison City, in: WG James \& M Simons (eds), The Angry Divide (Cape Town: David Philip).

Robins, S (2000) City sites: multicultural planning and the post-apartheid city, in: S Nuttall \& CA Michael (eds), Senses of Cultures: South African Culture Studies (Cape Town: Oxford University Press).

Robins, S (forthcoming) Limits to Liberation: Citizenship and Governance after Apartheid.

Salo, E (forthcoming) Race laws, gendered tactics: on becoming respectable mothers during the apartheid era, in: S Robins (ed) (2003) Limits to Liberation: Citizenship and Governance After Apartheid.

Scott, J (1998) Seeing like a state: how certain schemes to improve the human condition have failed (New Haven: Yale University Press).

Silverstone, R (1997) 'Introduction', in: R Silverstone (ed), Visions of Suburbia (London: Routledge).

Smith, D (ed) (1992) The Apartheid City and Beyond: Urbanisation and Social Change in South Africa (Johannesburg: Routledge/Witwatersrand University Press).

Spiegel, A, Watson, V \& Wilkinson, P (1999) Speaking truth to power: some problems using ethnographic methods to influence the formulation of housing policy in South Africa, in: A Cheater (ed), The Anthropology of Power: Empowerment and Disempowerment in Changing Structures (London: Routledge), pp. 175-190.

Steinberg, J (2001) Crime Wars: The South African Underwood and its Foes (Johannesburg: Witwatersrand University Press).

Swilling, M, Humphries, R \& Shubane, K (eds) Apartheid City in Transition (Cape Town: Oxford University Press).

Tomlinson, R (1994) Urban Development Planning: Lessons for the Economic Reconstruction of South Africa's Cities (Johannesburg: Witwatersrand University Press and London: Zed Books). 